\title{
THE INFLUENCE OF ONLINE MEDIA ADVERTISING AND PRODUCT QUALITY ON HONDA MOBILIO BUYING INTEREST THROUGH BRAND AWARENESS
}

(Survey in Region Three Cirebon) Ikin Sodikin ${ }^{1}$ ikinsodikin2907@gmail.com Wachjuni $^{2}$ wachjuni@uniku.ac.id

\begin{abstract}
This study aims to determine the direct and indirect effects of video advertising through online media and product quality on buying interest with brand awareness as an intervening variable. The sample in this study was people in the three regions of Cirebon with the category of having seen video advertisements on online media, having driven or bought a Honda Mobilio product and were over 20 years old with samples taken as many as 100 people. This research instrument in the form of a questionnaire by distributing through the help of Google forms. The data analysis technique used is Structural Equation Modeling (SEM). The test results of the proposed hypothesis show that (1) video advertising through online media has no effect on brand awareness and is significant. (2) video advertisements through online media have no effect on buying interest and are not significant. (3) product quality influences brand awareness and is significant. (4) product quality has no effect on buying interest and is not significant. (5) brand awareness has no influence on buying interest and is significant. (6) Variable video advertisements through online media and product quality together affect brand awareness. (7) video advertising through online media, product quality and brand awareness together influence buying interest. (8) video advertising through online media has no effect on buying interest through brand awareness. (9) product quality influences buying interest through brand awareness.
\end{abstract}

Keywords: Video Advertising Through Online Media, Product Quality, Buy Brand Awareness

Jel Classification : M37

\section{INTRODUCTION}

In the development of the automotive automotive industry in Indonesia, which is increasing with the size of the market continues to grow from year to year.
However, in 2019 car sales according to the Association of Indonesian Automotive Industries (GAIKINDO) recorded domestic car sales. The following is a chart of car sales for 2015-2019.

Figure 1

Total Domestic Car Sales from 2015 to 2019

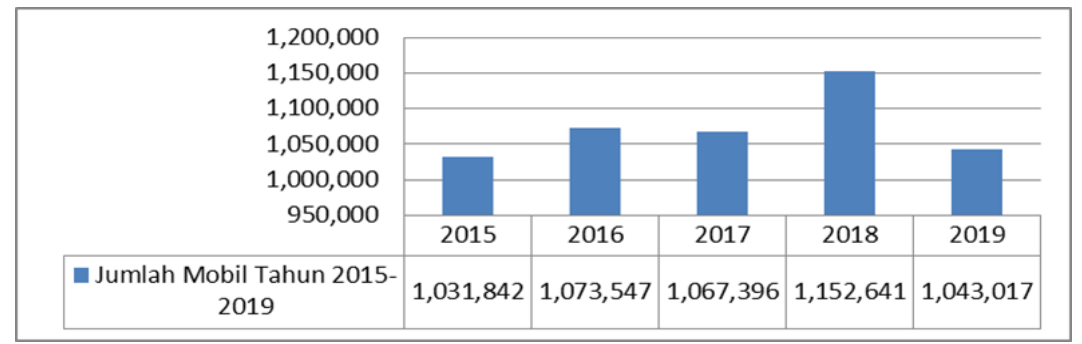

Source: www.motoris.id 
This can be used as evaluation material for automotive companies to try to make innovation and creativity. Automotive companies should provide a positive stimulus so as to increase public buying interest in cars. The highest market share in Indonesia is achieved by Low Multi Purpose Vehicle (LMPV). In 2018, the market share controlled $24.5 \%$ of total car sales or as many as 28 thousand units.

Honda car products with the Low MPV type are Honda Mobilio. This Honda-made car was previously introduced in Indonesia in 2014. Honda Mobilio is one of the family cars sold by Honda, where this car is carried as a Low MPV sedan because it is smaller than its competitors. Mobillio in 2019.

Table 1

Sales of Honda Mobilio Cars 2015-2019

\begin{tabular}{ll}
\hline Tahun & Penjualan/Unit \\
\hline 2015 & 42.932 \\
2016 & 39.482 \\
2017 & 35.430 \\
2018 & 24.373 \\
2019 & 15.318 \\
\hline
\end{tabular}

Source: www.motoris.id

One of the Honda dealers in Cirebon 3, namely, PT. Lambang Putra Perkasa Motor Cirebon or PT. LPPM Cirebon explained that Honda Mobilio sales had quite good sales, namely an annual average of 20 units / month with a market share of $15 \%$ in 2019 . This shows that interest in purchasing LMPV type cars is still there. However, the difference in sales occurs in other competing LMPV types, namely the Suzuki Ertiga, where according to the marketing manager, the sales of this car averaged 25 units / month or with a market share of $18.3 \%$ in 2019 . This proves that the interest in buying a car type LMPV Honda Mobilio is lower than the Suzuki Ertiga. (www.suara.com).

From the results above, there are differences in research conducted by other researchers including Herdaningtyas and Iriani (2017), it is explained that the purchase interest variable is directly influenced by advertising and brand awareness variables. However, the advertising variable has no effect on the brand awareness variable. Research conducted by Arifin and Facrodji (2015) explains that product quality does not affect consumer buying interest in Achilles tires in South Jakarta. Research conducted by Prasetiyo (2014), the results of his research, explains that advertising does not have a significant effect on consumer buying interest in Yamaha Mio GT motorbikes in Mojokerto. Research conducted by Roozy et.al, (2014) explains that brand awareness has no effect on purchase intentions.

From the sales strategy, there are several variables that have been researched by previous research which as the basis of this research are supported by the data obtained in the field. Several previous studies have shown that the results of video advertisements, product quality and brand awareness have an effect on buying interest. The results of research conducted by Slamet et.al (2015) explained that advertising and product quality have a direct effect on brand awareness. advertisement and product quality have also been shown to have a direct effect on purchase intention. brand awareness has a direct effect on purchase intention, brand awareness can mediate the relationship between advertising and purchase intention, and brand awareness can mediate the relationship between advertising and purchase intention, and brand awareness can mediate product quality on purchase intention.

Based on the existing problems, the research that the researcher wants to raise 
is "the effect of online media advertising and product quality on buying interest in Honda Mobilio through brand awareness"

\section{Theoretical basis \\ Interest Buying}

Morissan (2007) in Klele et.al, (2015) explains that purchase interest is a stage of purchasing decisions where at a point in the buying process, consumers must stop evaluating, consumers begin to lead to interest and desire to buy with a tendency to buy certain brands .

From this theory, it can be concluded that purchase interest is the attitude or behavior of consumers from the urge that comes from the consumer to have a product or service that appears with the influencing factor. Ferdinand (2002: 129) in DH Prasetiyo, (2014) states that buying interest can be identified through the following indicators: Transactional interest, referential interest, preferential interest, explorative interest.

\section{Brand Awareness}

According to Aaker (2011: 10) in Sumardiantono, (2017) Brand awareness is the ability of a prospective buyer to recognize and recall a brand as part of a certain product category. The role of brand awareness in brand equity depends on the level of attainment of awareness in the minds of consumers. Shimp (2003) explains in Apriliani and Kusumastuti, (2019) that brand awareness is the ability of a brand to appear in the memory of consumers when they are thinking about certain product categories and how easily the name comes up.

From this theory, it can be concluded that brand awareness is the ability of consumers to recognize or remember a brand from a certain category and how easily the name is remembered in it. Brand can be triggered by influencing factors such as advertisement, quality, image and so on. The variable of brand awareness according to Susanto and Wijanarko (2004) in D. Orlando, (2015) can be measured from 4 indicators used to determine how far consumers are aware of a brand, including: Recall, Recognition, Purchase, and Consumption.

\section{Advertisement}

Ralph E. Alexander, ed. (1995) in Morissan, MA, (2010) explained that advertising or advertising can be defined as "any paid form of non-personal communication about an organization, product service or idea by an identified sponsor" or any non-personal communication product about an organization, product, services or ideas paid for by a known sponsor.

According to the opinion of Gilson and Berkman (2002: 61) in Safriadi and Hardyaningwati, (2017) advertising is a persuasive communication medium designed to generate responses and help achieve marketing objectives or objectives. So, advertising can be concluded, namely the form of presenting non-personal messages to lead someone to an idea carried out by companies or marketers by spending a certain amount of money with advertising media through online and offline or print media in achieving marketing goals.

According to Lesmana (2014), according to Lee (2007) selecting good media for advertising in order to make consumers know, understand, determine attitudes, and make purchases is an important step in advertising activities. Several media options that can be used for advertising include: online media (internet), newspapers, magazines, radio, television, billboards (outdoor advertising), and direct mail. According to Tjetjep (2007) Djatnika in Lesmana, (2014), in order for advertising to successfully stimulate buying action, it must meet several criteria that explain the dimensions of advertising through indicators including: Attention, interest, desire, and action.

\section{Product Quality}

The definition of product quality according to Cannon et.al (2008: 286) in Zhahir and Widayanto, (2018) is the product's ability to satisfy consumer needs or desires. Kotler and Armstrong (2012: 283) in Kalele et.al, (2015) Product quality is the ability of a product to demonstrate its function. This 
includes the overall durability, reliability, accuracy, ease of operation, and product repair. Product quality for customer satisfaction and company profitability are closely related.

So, product quality can be concluded that is the best guarantee for customer loyalty and the strongest defense against competition that determines consumer satisfaction in meeting needs which include durability, reliability or progress, strength, ease of packaging and product repair and other characteristics that refer to on product standardization. According to Kotler and Armstrong (2004: 283) in Martono and Iriani (2014) the meaning of a product quality is "the ability of a product to perform its functions, it includes the product's overall durability, reliability, precision, ease of operation and repair, and other valued attributes ". Which means the ability of a product to demonstrate its function, it includes overall durability, reliability, accuracy, ease of operation and product repair as well as other product attributes. So in measuring product quality using 8 (eight) indicators, namely performance (product's performance), features (features), reliability (reliability), suitability (conformance), durability (serviceability), beauty (aesthetic). ) and perceived quality.

Framework

Figure 2

conceptual framework

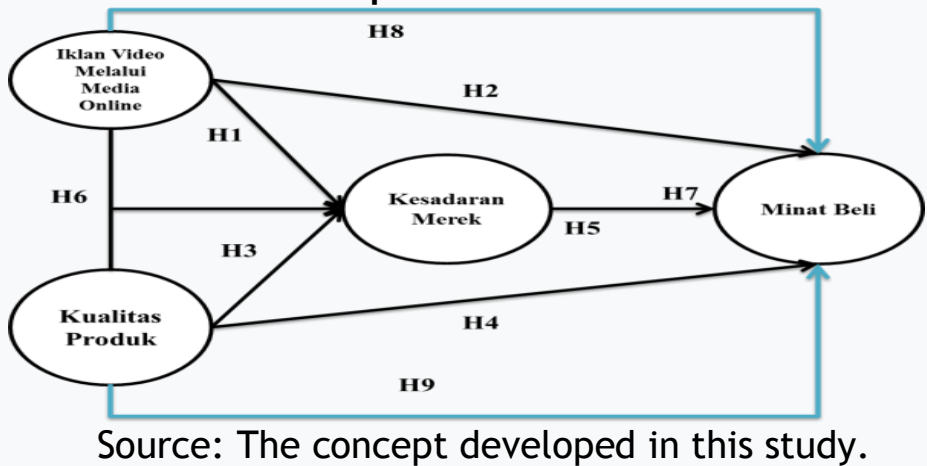

Information :

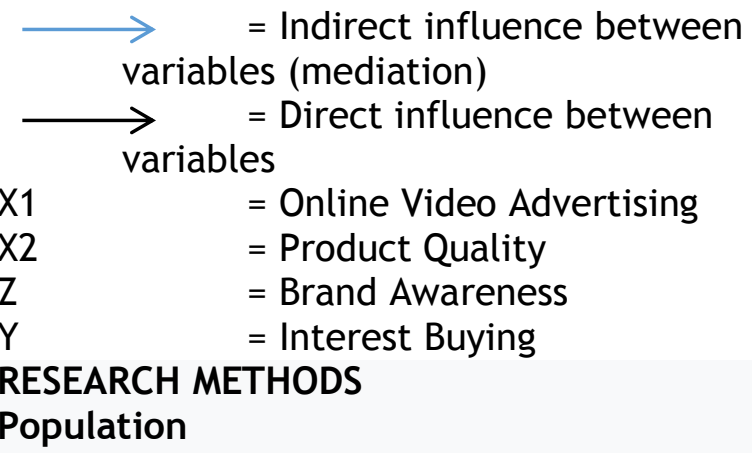

As for the population in this study are all consumers who know about video advertisements through online media and have ever tried Honda Mobilio in area three Cirebon. The limits set on this population are based on an unlimited number, are heterogeneous and are based on research surveys.
Sample

The sampling technique used in the study was a non-probability sampling technique with a purposive sampling approach. In this study, the sample used has the following criteria: Consumers who have seen video advertisements for Honda Mobilio brand cars in area Tiga Cirebon. Consumers who have used or owned Honda Mobilio cars and are interested in these products. Age 20 and over. And Willing and can be requested data.

Based on these considerations, the number of samples in this study was 100 respondents.

\section{Data analysis method}

Based on this research model, the researcher will use a data analysis technique, namely Structural Equation 
Modeling (SEM), which is operated through the AMOS program.

RESULTS AND DISCUSSION

Descriptive analysis
Of the 100 respondents who have been calculated, obtained data in the form of gender, age, occupation, address and length of use of the internet. The following is a table of respondents' profiles:

Table 3

Respondent Profile

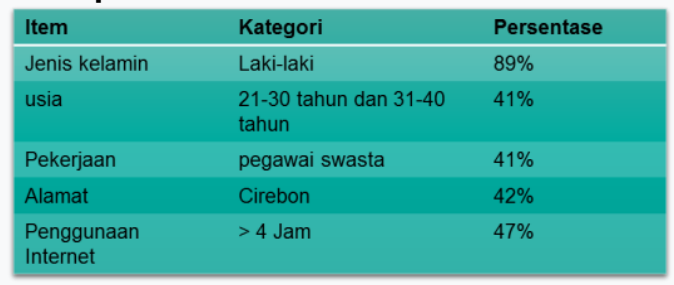

Source: Primary data processed, 2020

Table 3

Variable Index of Video Advertising Through Online Media, Product Quality, Brand Awareness and Purchase Intention

\begin{tabular}{cl}
\hline Varible & Index \\
\hline $\begin{array}{c}\text { Video advertising through online } \\
\text { media }\end{array}$ & $\mathbf{7 9 . 7 7 5 \%}$ \\
\hline
\end{tabular}

\begin{tabular}{cc} 
Product quality & $\mathbf{8 3 . 5 \%}$ \\
Brand Awareness & $\mathbf{8 1 . 1 \%}$ \\
Interest Buying & $\mathbf{8 1 . 6 \%}$ \\
\hline Source: Primary data processed, 2020
\end{tabular}

Because more than $70 \%$ is in accordance with the three box method, the 4 variables have a very high response.

\section{Analysis}

Full Model Structural Equation Modeling

Figure 3

Full Model Structural Equation Modeling

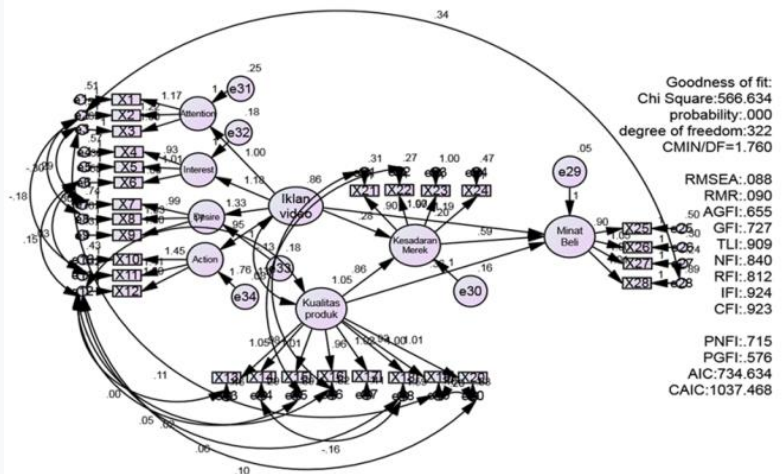

Source: Primary data processed, 2020 


\section{Discussion}

The Influence of Video Advertising Through Online Media on Brand Awareness The results showed that the video advertising variable through online media obtained a CR value of 1.346 with a probability of 0.051 . Because the probability value> 0.05 ; then this study proves that the first hypothesis does not prove that the effect of video advertising through online media on brand awareness.

The results of previous similar studies conducted by Herdaningtyas and Iriani (2017) which stated that advertising did not have a significant effect on brand awareness. Advertising cannot help respondents to remember a product. Advertising is a means of communication for products delivered through various media for a fee so that people are interested in agreeing and following the information. However, it is known that the awareness of the Honda Mobilio car brand is not influenced by video advertisements through online media. Advertising is a means of communication for products delivered through various media for a fee so that people are interested in agreeing and following the information. However, it is known that the awareness of the Honda Mobilio car brand is not influenced by video advertisements through online media.

The Effect of Video Advertising Through Online Media on Purchase Intention

The results showed that the video advertising variable through online media obtained a CR value of 0.958 with a probability of 0.115 . Because the probability value 0.05 ; then this study proves the second hypothesis does not prove that the effect of video advertising through online media on purchase intention. The results of previous similar studies conducted by Prasetiyo (2014) with a study entitled "The effect of advertising, formal products, and celebrity endosers on attitudes and buying interest of Yamaha Mio GT motorcycle consumers in Mojokerto". The results of his research explain that advertising does not have a significant effect on consumer buying interest in Yamaha Mio GT motorbikes in Mojokerto. This proves that not all advertisements can attract consumers to buy products. It is proven in this study that advertising through online media does not affect the interest in buying a Honda Mobilio car in area Tiga Cirebon.

The Effect of Product Quality on Brand Awareness.

The results showed that the product quality variable obtained a CR value of 4.473 with a probability of 0.008 . Because the probability value $<0.05$; then this study proves the third hypothesis is proven that the effect of product quality on brand awareness. The extent of the influence of product quality on meek awareness can be seen from the direct effect of the standardized estimate, which is 0.217 or $21.7 \%$. In accordance with the results of previous similar studies conducted by Slamet et.al, (2015) with a study entitled "The effect of YouTube pop-up ads and product quality on purchase intention with brand awareness as an intervening variable", it can be concluded that product quality directly affects brand awareness. This also proves that the quality of the product has an effect on the awareness of the Honda Mobilio car brand in area Tiga Cirebon.

The Effect of Product Quality on Purchase Intention

The results showed that the product quality variable obtained a CR value of 0.958 with a probability of 0.115 . Because the probability value> 0.05 ; then this study proves the fourth hypothesis does not prove that the effect of product quality on purchase intention.

The results of previous similar studies conducted by Arifin and Facrodji (2015) stated that product quality does not affect consumer purchase interest in Achilles tires in South Jakarta. These results prove that not all product quality can influence consumer purchase interest. This research 
proves that the quality of Honda Mobilio car products in Cirebon area has no effect on buying interest.

The Influence of Brand Awareness on Purchase Intention

The results showed that the brand awareness variable obtained a CR value of 1.671 with a probability of 0.013 . Because the probability value $<0.05$; then this study proves the fifth hypothesis that brand awareness has no effect on purchase intention. The results of a previous similar study conducted by Roozy et.al (2014) with a study entitled "Effect of brand equity on consumer purchase intention" explained that brand awareness had no effect on purchase intention. This is also proven in this study that awareness of the Honda Mobilio car brand has not been able to influence consumer buying interest in area Tiga Cirebon.

The Effect of Online Video Advertising and Product Quality on Brand Awareness

The results of data processing related to the influence between video advertising variables through online media and product quality on brand awareness with an $\mathrm{F}$-count value of 366,030 with $F$-table of 3.090 . This indicates that there is a significant influence between the variable variables of video advertising through online media and product quality on brand awareness.

The coefficient of determination obtained in this study was $88.3 \%$, while $11.7 \%$ was influenced by other factors such as brand image, perceived usefulness, brand equity, electronic word of mouth and so on. The results of a previous similar study conducted by Aulia (2019) with a study entitled "The Effect of Product Quality, Advertising, Promotion on Brand Awareness at the Heuvel Tribe Store Solo Distro" explains that advertising and product quality simultaneously influence brand awareness.

The Effect of Online Video Advertising, Product Quality and Brand Awareness on Purchase Intention

The results of data processing related to the influence between video advertising variables through online media, product quality and brand awareness on purchase intention with an $\mathrm{f}$-count value of 909,176 with an f-table of 2,698 . This indicates that there is a significant influence between the variable variables of video advertising through online media and product quality and brand awareness on purchase intention. The coefficient of determination obtained in this study is $96.6 \%$, while $3.4 \%$ is influenced by other factors such as celebrity endorsers, product design prices and others. This indicates a very large influence from video advertising through online media, product quality. and buying interest against buying interest. In line, according to Ujianto and Abdurachman (2004), the factors that influence buying interest include quality factors, brand / brand, packaging, price, availability of goods and references. So it can be concluded that buying interest is influenced by advertising, product quality and brand awareness.

Indirect Effect of Video Advertising Through Online Media on Purchase Intention through Brand Awareness as an Intervening Variable

Based on the results of research that has been done, it is known that the results of the indirect effect of video advertising through online media on purchase interest through brand awareness as an intervening variable are obtained (equal to -0.001) If the indirect effect is compared to the direct effect (amounting to -0.241) shows the greater than the indirect influence. So the brand awareness variable is not an intervening variable in the indirect effect of video advertising through online media on buying interest in this research. The results of a previous similar study conducted by Anitawati and Apriliano (2020) with a study entitled "Effect of brand equity on consumer purchase intention" explained that brand awareness had no effect on purchase intention. Meanwhile, according to Slamet et.al, (2015) that advertising can affect buying interest through brand awareness. This explains that brand awareness is not always able to mediate advertising to 
purchase intention. Thus, video advertising through online media cannot contribute to attracting buying interest in Honda Mobilio car products through brand awareness. Indirect Effect of Product Quality on Purchase Intention through Brand Awareness as an Intervening Variable

Based on the results of research that has been done, it is known that the results of the indirect effect of product quality on purchase intention through brand awareness as an intervening variable are obtained (amounting to 0.106). If the indirect effect is compared with the direct effect (amounting to -0.291), it shows a smaller result than the indirect effect. So the brand awareness variable is an intervening variable in this study.

The results of a previous similar study conducted by Slamet et.al, (2015) with a study entitled "The effect of YouTube popup ads and product quality on purchase intention with brand awareness as an intervening variable", it can be concluded that product quality indirectly affects interest. buying through brand awareness as an intervening variable which explains that brand awareness can mediate the effect of advertising on purchase intention. Thus, product quality can contribute to attracting interest in purchasing Honda Mobilio car products through awareness of the Honda Mobilio brand.

\section{CONCLUSION}

The conclusions obtained from this study are: First, the variable of video advertising through online media has no effect on brand awareness and is significant. This means that the video advertising strategy through online media carried out by the Honda car company on the Honda Mobilio brand has not provided good results in providing awareness of the Honda Mobilio brand; Second, the variable of video advertising through online media has no effect on purchase intention and is not significant. This means that the strategy of video advertising through online media carried out by Honda car companies for the Honda Mobilio brand has not provided good results in generating interest or desire to buy Honda Mobilio brand cars; Third, the variable product quality has a positive and significant effect on brand awareness. This means that the quality of the products carried out by the Honda car company on the Honda Mobilio brand can provide good results in providing awareness of the Honda Mobilio brand. The higher the quality of the product, the more aware of the brand; Fourth, the variable product quality has no effect on purchase intention and is not significant. This means that the quality of the products carried out by the Honda car company to the Honda Mobilio brand has not provided good results in generating consumer interest or desire in buying Honda Mobilio brand cars; Fifth, brand awareness variable has no effect on purchase intention and is significant. This means that awareness of the Honda Mobilio brand has not yielded good results in generating consumer interest or desire in buying Honda Mobilio brand cars; Sixth, the variable of video advertising through online media and product quality together has a positive effect on brand awareness. This could explain that video advertising through online media and product quality will have a direct effect in increasing awareness of the Honda Mobilio brand. The better the advertising strategy and product quality carried out will increase awareness of the Honda Mobilio car brand; Seventh, the variable of video advertising through online media, product quality and brand awareness together have a positive effect on purchase intention. This can explain that video advertising through online media, product quality and brand awareness have a direct effect in increasing interest in buying a Honda Mobilio car. The better the strategy carried out will increase the purchase interest in the product; Eighth, the variable of video advertising through online media has no effect on purchase intention through brand awareness. It is evident that the video advertising strategy through online media has not been able to attract Honda Mobilio car purchases, even through the awareness 
of the Honda Mobilio brand in area 3 Cirebon; Ninth, the variable of product quality has a positive effect on purchase intention through brand awareness. This proves that the quality of the product can attract the interest in buying Honda Mobilio cars and even increase awareness of the Honda Mobilio brand in area 3 Cirebon.

\section{REFERENCES}

Achmad, S. H., \& Hidayat, R. (2018). The Effect Of Video Advertisement By Beauty Vlogger On Buying Intention. International Journal Of Accounting, Finance, And Economics, (E-Issn: $2597-$ 971x Dan P-Issn: 2597-9728 This), 1-6.

Anitawati, M.Th. dan Apriliano, A (2020) Iklan YouTube dan Brand Awareness serta Pengaruhnya terhadap Minat Beli. Universitas Bakrie. (Unpublished).

Apriliani, N. E., \& Kusumastuti, A. E. (2019). Pengaruh Promosi Terhadap Minat Beli Pada Wuling Motors Dengan Kesadaran Merek Sebagai Variabel Mediasi. Jurnal Administrasi Bisnis (Jab), 2, 333-340.

ARF, (2020 28 Januari). "Penjualan Babak Belur, Honda Mobilio Anyar Segera Meluncur" [Online], Tersedia: https://www.motoris.id/autokritik/32 397/32397/. [8 Februari 2020]

Armyanto, Indra (13 Agustus 2018). "Pentingnya Brand Awareness Bagi Perusahaan" [Online], Tersedia: https: / / rumahasyam.com/pentingnyabrand-awareness-bagi-perusahaan/. [9 agustus 2020]

Aulia, M. A., Agus, S., \& Sos, S. (2019). Pengaruh Kualitas Produk, Advertising, Promosi Terhadap Brand Awareness Pada Distro Heuvel Tribe Store Solo (Doctoral Dissertation, lain Surakarta).

Chabibi, I., Hasiholan, L. B., \& Harini, C. (2018). Pengaruh Kualitas Layanan, Citra Merk Dan Kualitas Produk Terhadap Keputusan Pembelian Dengan Minat Pembelian Sebagai Intervening (Studi Kasus Dealer Jaya Motor Semarang). Journal of Management, 4(4).
Chi, H. K. (2009). The Impact Of Brand Awareness On Consumer Purchase Intention: The Mediating Effect Of Perceived Quality And Brand Loyalty. The Journal of International Management Studies, 4(1), 135-144.

Cornelius Candra, (2019, 29 Maret). "Ini Deretan Mobil MPV Baru yang Melantai di GIIAS 2019 Surabaya" [Online], Tersedia:

https: //www.otosia.com/berita/inideretan-mobil-mpv-baru-yangmelantai-di-giias-2019-surabaya.html, [11 November 2019].

Dimiaty, C. R. (2007). Efektivitas Iklan Point Of Purchase On3 Photo Company Grand City Surabaya. Jurnal E-Komunikasi, 5(2), 1-10.

Ekarina, (2019, 17 Juli). "Penjualan Mobil Domestik Merosot 13\% di Semester I 2019" [Online], Tersedia :https://katadata.co.id/berita/2019/0 7/17/penjualan-mobil-domestikmerosot-13-di-semester-i-2019, November 2019].

Fachrodji, E. A. Dan A. (2015). Pengaruh Persepsi Kualitas Produk, Citra Merek Dan Promosi Terhadap Minat Beli Konsumen Ban Achilles Di Jakarta Selatan. Jurnal Mix, V(1), 124-143.

Fauzan, A., \& Rohman, A. (2019). Pengaruh Harga Dan Kualitas Produk Terhadap Minat Beli Sepeda Motor Kawasaki. Jurnal Ekobis: Ekonomi Bisnis \& Manajemen, 9(2), 104-113.

Ferawati, I. (2010). Bootstrap Dalam Structural Equation Modeling ( Sem ) Untuk Mengatasi Asumsi Non-Normal Multivariat.

Hardyaningwati, S. Dan. (2017). Pengaruh atribut Produk Dan Iklan Terhadap Minat Beli Kendaraan Bermotor Jenis Metic Merek Hondapadapt. Astrahondamotor Jakartatimur. Jurnal Riset Dan Aplikasi: Akuntansi Dan Manajemen, 4(2011), 204-210.

Haryono, W. (2016). I Metode SEM Untuk Penelitian Manajemen dengan AMOS LISREL PLS ini (M. Dwi Puryanto, SE, ed.). Jl. Duta Bumi Raya No. 1 Kota 
Harapan Indah, Bekasi, Jawa Barat 17131: Hamid Mintardja, SE, MM.

Herdaningtyas, G., \& Iriani, F. (2017). Pengaruh Iklan Dan Penggunaan Selebritas Dalam Iklan Terhadap Minat Beli Produk Melalui Kesadaran Merek Sebagai Variabel Intervening. Prosiding Seminar Nasional Ekonomi Dan Bisnis (Snebis), 1(1), 1.

Hestanto, (2016). "Konsep Dasar Periklanan Video" [Online], Tersedia: https: / /www.hestanto.web.id/perikla nan-video/. [6 November 2019].

http://www.gaikindo.or.id

https: / /www.worldometer.com

Ibrahim, A. C. (2016). Pengaruh Kesadaran Merek, Asosiasi Merek, Loyalitas Merek, Citra Merek Dan Persepsi Kualitas Terhadap Ekuitas Merek Smartphone Di Surabaya (Doctoral dissertation, STIE Perbanas Surabaya).

Indah, K., \& Budiatmo, A. (2018). Pengaruh Brand Image dan Brand Awareness Terhadap Minat Beli Sepeda Motor Honda Scoopy dengan Minat Beli sebagai Variabel Intervening (Studi Kasus Pada Konsumen PT. Nusantara Sakti di Kota Semarang). Jurnal Ilmu Administrasi Bisnis, 7(5), 113-122.

Infantri, A. D. W. I. (2014). Pengaruh Dimensi Kualitas Produk Terhadap Niat Beli Honda Cb150r Streetfire Di Surabaya. Jurnal Ilmiah Manajemen, 2(April), 293-305.

Joel, G., \& Sepang, J. D. D. M. J. L. (2014). Pengaruh Motivasi, Persepsi Harga, Dan Kualitas Produk Terhadap Minat Beli Konsumen Sepeda Motor Matic Merek Yamaha Mio Di Kota Manado. Jurnal Emba, 2(3), 1463-1472.

Kalele, B., Oroh, S. G., \& Sumarauw, J. (2015). Pengaruh Word of Mouth, Daya Tarik Iklan, Persepsi Harga Dan Kualitas Produk Terhadap Minat Beli Motor Suzuki Satria Fu Pada Pt. Sinar Galesong Mandiri. Jurnal EMBA: Jurnal Riset Ekonomi, Manajemen, Bisnis dan Akuntansi, 3(3).

Khoiriatun Nafilah, A. W., \& Suharto, M. K. A. B. (2013). Pengaruh Kualitas Produk
Dan Harga Terhadap Keputusan Pembelian Dan Minat Beli Sebagai Variabel Intervening (Study. E - Jurnal Riset Manajemen Prodi Manajemen, 98-108.

Kontributor Wikipedia. "Honda." Wikipedia, Ensiklopedia Bebas. Wikipedia, Ensiklopedia Bebas, 6 Apr. 2020. Web. 6 Apr. 2020.

Kotler, Philip, (2009). Manajemen Pemasaran, Edisi 13, Jilid 1, Jakarta,Erlangga.

Kotler, Philip, (2009). Manajemen Pemasaran, Edisi 13, Jilid 2, Jakarta,Erlangga.

Kurnyawati, M. D., \& Yulianto, E. (2014). Pengaruh Iklan Terhadap Brand Awareness Dan Dampaknya Terhadap Keputusan Pembelian (Studi Pada Mahasiswa Fakultas Ilmu Administrasi (Fia) Jurusan Administrasi Bisnis Universitas Brawijaya Angkatan 20122013 Yang Menggunakan Produk Sabun Mandi Merek Lifeboy. Jurnal Administrasi Bisnis (Jab), 16(1), 1-6.

Lesmana, A. S. (2014). Analisis Pengaruh Iklan, Persepsi Kemudahan, Dan Reputasi Terhadap Minat Beli Handphone Pada Situs Layanan Iklan Baris Online (Studi Pada Tokobagus. Com).

Lim, Y., Yap, C., \& Lau, T. (2011). The Effectiveness Of Online Advertising In Purchase Decision : Liking, Recall And Click. Australian Journal Of Basic And Applied Sciences, 5(9), 1517-1524.

Lukman Fuad (27 Desember 2013). "Minat Beli" [Online] Tersedia: https: / / kantinpustaka.blogspot.com/2 013/12/minat-beli.html [5 Juli 2020]

Martins, J., Costa, C., Oliveira, T., Gonçalves, R., \& Branco, F. (2018). How Smartphone Advertising In Fl Uences Consumers , Purchase Intention. Journal of Business Research, (December 2017), 1-10. Https://Doi.Org/10.1016/J.Jbusres.20 $\underline{17.12 .047}$

Martono, R. (2014). Analisis pengaruh kualitas produk, harga dan promosi 
terhadap minat beli konsumen produk batik sendang duwur Lamongan. Jurnal IImu Manajemen (JIM), 2(2)

Massie, J. D. D., \& Tumbuan, W. J. F. A. (2019). The Influences Of Product, Price, After Sales Service And Advertising On Consumer Purchase Intention Of Mpv Car ( Case Study Of Suzuki Ertiga ) Pengaruh Produk , Harga , Layanan Purna Jual Da. Jurnal Emba, 7(4), 4651-4661.

Morissan, M.A. (2010). Periklanan Komunikasi Pemasaran Terpadu, Edisi 1, Jakarta, Kencana prenada media group..

Muchlisin Riadi, (2018 21 Des). "Aspek, Jenis, Tahapan dan Faktor yang Mempengaruhi Minat Beli" [Online], Tersedia:

https: / /www.kajianpustaka.com/2018 /12/aspek-jenis-tahapan-dan-faktoryang-mempengaruhi-minat-beli.html. [8 November 2019]

Novi Tria Mardalena1, A. Rahman Lubis2, S. U. (2018). Pengaruh Kesadaran Merek, Kepercayaan Merek Dan Keunggulan Produk Terhadap Minat Beli Produk Luxuri Fashion Brand Dengan Gender Sebagai Moderating Pada Pemasaran Media Sosial Di Kota Banda Aceh. Jurnal Magister Manajemen Fakultas, 2(1), 99114.

Orlando, D. (2015). Analisa Pengaruh Brand Image Dan Brand Awareness Terhadap Purchase Intention Sepeda Motor “ Kawasaki Ninja 250fi “. Jurnal Managemen Pemasaran Petra, 3(1), 19.

Pranata, I. W. D. R. dan Km. Agus Satria Pramudana. 2018. Peran Kesadaran Merek (Brand Awareness) Dalam Memediasi Hubungan Iklan Oppo Dengan Niat Beli Konsumen. E-Jurnal Manajemen Unud, 7(10), 5230-5257.

Prasetiyo, D. H. (2014). Pengaruh Iklan, Produk Formal, Dan Celebrity Endoser Terhadap Sikap Dan Minat Beli Konsumen Sepeda Motor Yamaha Mio Gt
Di Mojokerto. Jurnal Administrasi Bisnis (Jab). Retrieved From Harrystar99@Yahoo.Com

Prastiti, M. D. A. A. E. (2018). Pengaruh Kualitas Produk, Citra Merek, Dan Harga Terhadap Minat Beli Produk Sepeda Motor Honda (Studi Padamahasiswa Fakultas Ekonomi Manajemen Universitas Kadiri). Jimek, 1(26212374), 67-78.

Roozy, E., Arastoo, M. A. L. I., \& Vazifehdust, H. (2014). Effect Of Brand Equity On Consumer Purchase Intention Brand Equity Purchase Intention - Brand Associations - Willing Purchase - Brand Awareness - Considering Purchase • Perceived Quality - Recommendation Purchase - Brand Loyalty. Indian J.Sci.R, 6(1), 212-217.

Saputra Randi. (2018). Pengaruh Iklan Dan Citra Merek Terhadap Minat Beli Konsumen Produk Merek Honda. Jom Fisip, 5, 1-19.

Setiawan, R. I. (2008). Pengaruh Iklan Dan Merek Sepeda motor Suzuki Terhadap Minat Beli Konsumen. Jurnal Kompilasi Ilmu Ekonomi, 2(0342), 34-52.

Slamet, H. P. C., Rachma, N., \& Hufron, M. (2019). Pengaruh Iklan Pop-Up Youtube Dan Kualitas Produk Terhadap Minat Beli Dengan Kesadaran Merek Sebagai Variabel Intervening. Jurnal Ilmiah Riset Manajemen, 8(16).

Sugiardi, A. B. (2017). Pengaruh Iklan Dan Atribut Produk Terhadap Brand Awareness Pada Produk Hufagripp. Jurnal Pendidikan Tata Niaga (Jptn), 03(03), 30-35.

Sugiono, (2012) Metode penelitian Kuantitatif kualitatif dan R\&D, Bandung, Alfabeta

Sukamto, S. M. A., \& Wijaksana, T. I. (2017). Iklan Melalui Youtube dan Minat Beli Produk. Jurnal Riset dan Aplikasi: Akuntansi dan Manajemen, 2(2), 135140.

Sumardiantono, T. (2017). Pengaruh Bintang Iklan, Citra Merek, dan Kesadaran Merek Terhadap Niat Beli Motor Honda 
Vario Di Pasuruan (Doctoral dissertation, STIE Perbanas Surabaya).

Ujianto, U., \& Abdurachman, A. (2004). Analisis Faktor-Faktor yang Menimbulkan Kecenderungan Minat Beli Konsumen Sarung (Studi Perilaku Konsumen Sarung di Jawa Timur). Jurnal Manajemen dan kewirausahaan, 6(1), pp-34.

Waluyo, M. (2016). Mudah Cepat Tepat Penggunaan Tools Amos Dalam Aplikasi ( SEM ). UPN “VETERAN” JATIM.

Widhiarso, W. (2012). Pemodelan Persamaan Struktural ( Sem ) Pada Data Yang Tidak Normal. 1-12.

Yogi Saputro, D. P. (2018). Television Advertising Effectiveness In Mediating Advertising Creativity And Advertising Frequency Influence Toward Customer Purchase Intention. Management Analysis Journal, 7(2).

Yuniyanto, H. R., \& Sirine, H. (2018). Pengaruh Iklan Terhadap Minat Beli Pengguna Youtube Dengan Brand Recognition Sebagai Variabel Intervening. Jurnal Bisnis Manajemen, 8(September 2017), 21-28. Https: / /Doi.Org/10.15408/Ess.V8i1.58 85

Zainuddin, D. (2018). Pengaruh Kualitas Produk Dan Brand Image Terhadap Minat Beli Motor Matik. Jurnal Sosio EKons, 10(3), 220-227.

Zhahir, B., \& Widayanto, W. (2018). Pengaruh Kualitas Produk dan Iklan Terhadap Keputusan Pembelian Melalui Minat Beli Sepeda Motor Yamaha NMAX (Studi kasus pada Dealer Yamaha Bahana Pekalongan). Jurnal Ilmu Administrasi Bisnis, 7(5), 146-154 